\title{
Penggunaan SPSS Untuk Pembuktian Kebenaran Hukum Ohm
}

\author{
Ulul Ilmi *) \\ ${ }^{*}$ Program Studi Elektro Fakultas Teknik Universitas Islam Lamongan
}

\begin{abstract}
Abstraksi
Dalam penelitian ini pembuktian kebenaran hukum ohm akan diselesaikan dengan bantuan softwaere SPSS dengan menggunakan uji validasi korelasi pearson.Adapun data yang akan diuji kebenarannya bersumber dari hasil percobaan Tuan Ohm pada lampu 1. Untuk menyelesaikan persoalan pembuktian kebenaran hukum Ohm maka dapat digunakan bantuan SPSS ditempuh melalui beberapa tahapan sebagai berikut : (1) Menformulasikan persoalan pembuktian kebenaran hukum ohm ke dalam tabel SPSS, (2) Menuliskan koefisien dari variabel arus dan beda potensial listrik pada tabel SPSS sebagai representasi dari percobaan Tuan George Simon Ohm (3) Menuliskan simbol dari variabel arus dan beda potensial listrik pada tabel SPSS sebagai representasi dari percobaan Tuan George Simon Ohm, (5) Melakukan running program SPSS sebagai jawaban atas persoalan pembuktian kebenaran hukum ohm, (6) Nilai hasil perhitungan SPSS merupakan nilai korelasi arus dan beda potensial listrik sebagai solusi dari persoalan pembuktian kebenaran hukum ohm, (7) Jika diinginkan bisa menuangkan hasil penelitian dalam bentuk web.
\end{abstract}

\section{Kata-kata kunci : sistem persamaan garis linear, hukum ohm linear dan SPSS}

\section{Latar Belakang}

\section{I.PENDAHULUAN}

Penelitian ini membahas penggunaan program SPSS untuk membuktikan kebenaran hukum ohm. Seorang ilmuwan Jerman, George Simon Ohm (1789-1854), dalam penelitiannya menemukan adanya hubungan antara beda potensial ujung-ujung penghantar dengan kuat arus yang mengalir pada penghantar tersebut. Berikut hasil percobaan Tuan George Simon Ohm :

Tabel 1. Beda Potensial dan kuat arus pada lampu 1

\begin{tabular}{ccccc}
\hline No & $\begin{array}{c}\text { Jumlah batu } \\
\text { baterai }\end{array}$ & $\begin{array}{c}\text { Beda } \\
\text { potensial } \\
(\mathrm{V})\end{array}$ & $\begin{array}{c}\text { Kuat } \\
\text { arus (I) }\end{array}$ & $\begin{array}{c}\mathrm{Ohm}= \\
\mathrm{V} / \mathrm{I}\end{array}$ \\
\hline 1 & 1 & 1.5 & 0.05 & 30 \\
\hline 2 & 2 & 3.0 & 0.10 & 30 \\
\hline 3 & 3 & 4.5 & 0.15 & 30 \\
\hline 4 & 4 & 6.0 & 0.20 & 30 \\
\hline 5 & 5 & 7.5 & 0.25 & 30 \\
\hline
\end{tabular}

Untuk membuktikan kebenaran Hukum Ohm maka digunakan uji validasi korelasi pearson dengan memanfaatkan SPSS

\section{Rumusan Masalah}

Berdasarkan uraian latar belakang diatas, maka dapat dirumuskan permasalahan penelitian sebagai berikut : Bagaimana cara memanfaatkan SPSS untuk penyelesaian pembuktian kebenaran hukum ohm ?

\section{Batasan Masalah}

Penelitian ini membatasi masalah hanya pada pembuktian kebenaran hukum ohm berdasarkan Beda Potensial dan kuat arus pada lampu 1

\section{Tujuan Penelitian}

Penelitian ini adalah untuk mengetahui bagaimana cara memanfaatkan SPSS untuk penyelesaian pembuktian kebenaran hukum ohm

\section{METODOLOGI}

Dalam penelitian ini akan dijelaskan diagram blok penelitian cara memanfaatkan SPSS untuk penyelesaian pembuktian kebenaran hukum ohm seperti terlihat pada gambar 1.

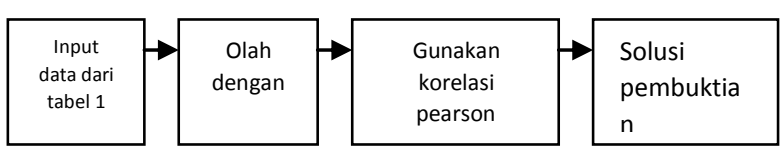

Gambar 1. Diagram blok penelitian

Pertama data diinputkan dari tabel 1 ke dalam tabel SPSS. Setelah semua data sudah diinputkan dan semua variabel sudah ditentukan type datanya atau jenis data nya maka langkah selanjutnya adalah dirunning. Nilai koefisien korelasi pearson yang telah dihasilkan dari perhitungan software SPSS merupakan nilai yang menginterpretasikan apakah terdapat hubungan yang erat antara variabel beda tegangan listrik terhadap kuat arus . Hasil penelitian selanjutnya jika dikehendaki bisa dituangkan dalam bentuk web.

\section{Besaran Listrik}

Rangkaian listrik dalam penelitian ini merupakan rangkaian yang terdiri dari beberapa sumber tegangan dc yaitu batery, serta tahanan listrik yang distel tetap pada nilai tertentu misalkan $30 \mathrm{Ohm}$. Pada percobaan kesatu digunakan sumber tegangan 1 batery senilai 1,5 volt sehingga didapatkan nilai arus listrik sebesar 0,05 ampere. Sedangkan pada percobaan kedua dipasang sumber tegangan 2 bateray nilanya menjadi 3 volt sehingga diperoleh nilai arus listrik benilai 0,1 ampere. Demikian seterusnya sampai pada percobaan terakhir yaitu percobaan kelima. 


\section{Sistem Persamaan Garis Linear}

Sistem persamaan garis linear dalam penelitian ini mewakili besaran hambatan listrik $\mathrm{R}_{\mathrm{xy}}$, besaran arus listrik $\mathrm{I}_{\mathrm{xy}}$ dan beda potensial listrik $\mathrm{V}_{\mathrm{xy}}$. Untuk menyusun sistem persamaan garis linear digunakan pedoman persamaan matematis dalam bentuk :

$\mathrm{I}=\mathrm{Vx}+\mathrm{R}$........(1)

dimana $\mathrm{V}$ mewakili besaran listrik tegangan listrik satuannya volt, $\mathrm{R}$ menyatakan hambatan listrik bersatuan ohm dan I menyatakan arus listrik memiliki satuan ampere.

Dalam penelitian ini diagram alir (flowchart) yang digunakan untuk penyelesaian pembuktian kebenaran hukum ohm ini adalah sebagai berikut :

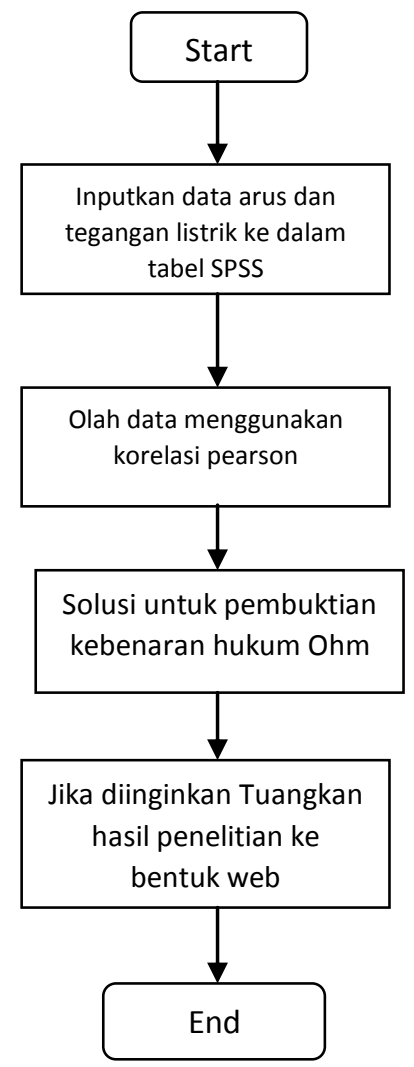

\section{Gambar 3. diagram alir pembuktian kebenaran hukum ohm}

Adapun penjelasan diagram alir penyelesaian pembuktian kebenaran hukum ohm adalah :

1. Inputkan data arus dan tegangan listrik ke dalam tabel SPSS.

2. Olah data tersebut menggunakan korelasi pearson.

3. Hasil olah data tersebut digunakan sebagai pembuktian kebenaran hukum Ohm tersebut.

4. Jika dikehendaki maka hasil penelitian dituangkan dalam bentuk web.

\section{Hyperlink ke halaman web}

Dalam penelitian ini sebuah halaman web memiliki link atau hyperlink (penghubung) ke halaman-halaman web yang lain. Untuk membuat link ke halaman lain, maka digunakan pasangan tag $\langle\mathrm{A}\rangle \ldots \ldots . .<\quad / \mathrm{A}\rangle$ atau yang biasa disebut tag jangkar atau anchor tag. Bentuk paling sederhana penggunaan tag jangkar adalah sebagai berikut :

$<\mathrm{A} \quad \mathrm{HREF}=\quad$ "URL" $>$ Label $</ \mathrm{A}>$

Dalam hal ini, URL (Uniform Resource Locator) dapat berupa alamat suatu dokumen web atau berkas grafik. Contoh URL tersederhana berupa nama berkas HTML.

\section{HASIL PENELITIAN}

Setelah dilakukan perhitungan dengan bantuan software SPSS maka didapatkan hasil sebagai berikut :

\section{Correlations}

\begin{tabular}{lcrr}
\multicolumn{4}{c}{ Descriptive Statistics } \\
\hline & $\begin{array}{c}\text { Std. } \\
\text { Mean }\end{array}$ & Deviation & $\mathrm{N}$ \\
\hline jumlahbate & 3.00 & 1.581 & 5 \\
rai & & & \\
V & 4.500 & 2.3717 & 5 \\
I & .1500 & .07906 & 5 \\
Ohm & 30.00 & .000 & 5 \\
\hline
\end{tabular}

Pada Tabel descriptive statistics berisi informasi tentang rata-rata (mean), standard deviasi dan jumlah data dari setiap variabel jumlah baterai, V, I dan $\mathrm{Ohm}$.

\begin{tabular}{|c|c|c|c|c|c|}
\hline & & $\begin{array}{c}\text { jumlahb } \\
\text { aterai }\end{array}$ & V & I & Ohm \\
\hline \multirow[t]{3}{*}{$\begin{array}{l}\text { Jumlahbat } \\
\text { erai }\end{array}$} & $\begin{array}{l}\text { Pearson } \\
\text { Correlation }\end{array}$ & 1 & $\begin{array}{r}1.00 \\
0^{* * *}\end{array}$ & $1.000_{*}^{*}$ & ${ }^{\mathrm{a}}$ \\
\hline & Sig. (2-tailed) & & .000 & .000 & . \\
\hline & $\mathrm{N}$ & 5 & 5 & 5 & 5 \\
\hline \multirow[t]{3}{*}{$\mathrm{V}$} & $\begin{array}{l}\text { Pearson } \\
\text { Correlation }\end{array}$ & $1.000^{* *}$ & 1 & $1.000_{*}^{*}$ &.$^{\mathrm{a}}$ \\
\hline & Sig. (2-tailed) & .000 & & .000 & \\
\hline & $\mathrm{N}$ & 5 & 5 & 5 & 5 \\
\hline \multirow[t]{3}{*}{ I } & $\begin{array}{l}\text { Pearson } \\
\text { Correlation }\end{array}$ & $1.000^{* *}$ & $\begin{array}{l}1.00 \\
0^{* * *}\end{array}$ & 1 &.$^{\mathrm{a}}$ \\
\hline & Sig. (2-tailed) & .000 & .000 & & \\
\hline & $\mathrm{N}$ & 5 & 5 & 5 & 5 \\
\hline \multirow[t]{3}{*}{ Ohm } & $\begin{array}{l}\text { Pearson } \\
\text { Correlation }\end{array}$ &.$^{\mathrm{a}}$ &.$^{\mathrm{a}}$ &.$^{\mathrm{a}}$ &. \\
\hline & Sig. (2-tailed) & - & . & . & \\
\hline & $\mathrm{N}$ & 5 & 5 & 5 & 5 \\
\hline
\end{tabular}

**. Correlation is significant at the 0.01 level (2-tailed).

a. Cannot be computed because at least one of the variables is constant. 
Berdasarkan hasil ini maka dapat disimpulkan bahwa pembuktian kebenaran hukum ohm dapat diselesaikan dengan bantuan SPSS. Selanjutnya hasil penelitian jika dikehendaki bisa dituangkan dalam bentuk web.

\section{PENUTUP}

\section{Kesimpulan}

Berdassrkan hasil penelitian yang telah dilakukan dapat diambil kesimpulan sebagai berikut :

1. Untuk menyelesaikan persoalan pembuktian kebenaran hukum Ohm maka dapat digunakan bantuan SPSS ditempuh melalui beberapa tahapan sebagai berikut : (1) Menformulasikan persoalan pembuktian kebenaran hukum ohm ke dalam tabel SPSS, (2) Menuliskan koefisien dari variabel arus dan beda potensial listrik pada tabel SPSS sebagai representasi dari percobaan Tuan George Simon Ohm (3) Menuliskan simbol dari variabel arus dan beda potensial listrik pada tabel SPSS sebagai representasi dari percobaan Tuan George Simon Ohm, (5) Melakukan running program SPSS sebagai jawaban atas persoalan pembuktian kebenaran hukum ohm, (6) Nilai hasil perhitungan SPSS merupakan nilai korelasi arus dan beda potensial listrik sebagai solusi dari persoalan pembuktian kebenaran hukum ohm, (7) Jika diinginkan bisa menuangkan hasil penelitian dalam bentuk web.

\section{Saran}

Penelitian ini dapat dilanjutkan untuk menyelesaikan persoalan lain yang masih berhubungan dengan sistem persamaan garis linear baik yang terdapat di dalam bidang teknik dan di luar bidang teknik.

\section{Daftar Pustaka}

[1] Abdul Kadir, Pemrograman Web. Jogjakarta, Andi Offset. 2002. Edisi tiga.

[2] Bambang Triatmodjo, Metode Numerik. Jogjakarta, Beta Offset. 1998.

[3] Barnawi, M.O.Tjia, Elektronika Terpadu 1. Jakarta, Erlangga. 1999.

[4] Barnawi, M.O.Tjia, Elektronika Terpadu 2. Jakarta, Erlangga. 1999.

[5] Dosen-Dosen Fisika ITS, Diktat Kuliah Fisika 1. Surabaya, Jurusan Fisika. 2004

[6] Jogiyanto, Pemrograman Turbo Pascal. Jogjakarta, Andi Offset. 2003. Edisi lima.

[7] Mathlab 5.3.1. tersedia di www.mathworks.com.

[8] Rahmond P. Canale, Steven C. Chapra, Metode Numerik Untuk Teknik. Jakarta, Universitas Indonesia Press. 1991.

[9] Sandi Setiawan. Simulasi, Teknik Pemrograman dan Metode Analisis, Jogjakarta Andi Offset. 1999.

[10] Sears Zemansky, Fisika Untuk Universitas 1. Jakarta, Rineka Cipta. 2001.

[11] Sears Zemansky, Fisika Untuk Universitas 2. Jakarta, Rineka Cipta. 2003.

[12] Sumisjokartono, Elektronika Praktis. Jakarta, Elex Media Komputindo. 1994.

[13] Sutrisno, Seri Fisika Dasar. Bandung, ITB. 1998.
[14] Warsito, Sirkuit Arus Searah. Jakarta, Karya Utama. 1995. 
